\title{
MYCELIAL GLUCOAMYLASES PRODUCED BY THE THERMOPHILIC FUNGUS SCYTALIDIUM THERMOPHILUM STRAINS 15.1 AND 15.8: PURIFICATION AND BIOCHEMICAL CHARACTERIZATION
}

\author{
M.S. Ferreira-Nozawa ${ }^{1,2}$; J.L. Rezende ${ }^{2}$; L.H.S. Guimarães ${ }^{2}$; H.F. Terenzi² ${ }^{2}$ J.A. Jorge ${ }^{2}$; M.L.T.M. Polizeli²* \\ ${ }^{1}$ Centro de Ensino Superior Nilton Lins, Manaus, AM, Brasil; ${ }^{2}$ Departamento de Biologia, Faculdade de Filosofia, Ciências e \\ Letras de Ribeirão Preto, Universidade de São Paulo, Ribeirão Preto, SP, Brasil.
}

Submitted: October 01, 2007; Returned to authors for corrections: December 24, 2007; Approved: May 04, 2008.

\begin{abstract}
Two strains (15.1 and 15.8) of the thermophilic fungus Scytalidium thermophilum produced high levels of intracellular glucoamylases, with potential for industrial applications. The isoform I of the glucoamylase produced by 15.1 strain was sequentially submitted to DEAE-Cellulose and CM-Cellulose chromatography, and purified 141 -fold, with 5.45\% recovery. The glucoamylase of strain 15.8 was purified 71 -fold by CMCellulose and Concanavalin A-Sepharose chromatography, with $7.38 \%$ recovery. Temperature and $\mathrm{pH}$ optima were in the range of $50-60^{\circ} \mathrm{C}$ and 5.0-6.0, respectively, using starch and maltose as substrates. The glucoamylase of $S$. thermophilum 15.8 was more stable $\left(\mathrm{t}_{50}>60 \mathrm{~min}\right)$ than that of $S$. thermophilum $15.1\left(\mathrm{t}_{50}=11-15 \mathrm{~min}\right)$, at $60^{\circ} \mathrm{C}$. The glucoamylase activities were enhanced by several ions $\left(e . g . \mathrm{Mn}^{2+}\right.$ and $\left.\mathrm{Ca}^{2+}\right)$ and inhibited by $\beta-$ mercaptoethanol. The glucoamylase from 15.1 strain showed a Km of $0.094 \mathrm{mg} / \mathrm{ml}$ and $0.029 \mathrm{mg} / \mathrm{ml}$ and Vmax of $202 \mathrm{U} / \mathrm{mg}$ prot and $109 \mathrm{U} / \mathrm{mg}$ prot, for starch and maltose, respectively. The hydrolysis products of starch and maltose, analyzed by TLC, demonstrated glucose as end product and confirming the character of the enzyme as glucoamylase. Differences were observed in relation to the products formed with maltose as substrate between the two strains studied. S. thermophilum 15.8 formed maltotriose in contrast with $S$. thermophilum 15.1 .
\end{abstract}

Key-words: glucoamylase, amylase, Scytalidium thermophilum, thermostable enzyme, starch hydrolysis

\section{INTRODUCTION}

Glucoamylases (GAs) (EC 3.2.1.3) are exo-amylases which hydrolyze $\alpha-1,4$ glycosidic linkages in raw or soluble starches and related oligosacharides, producing $\beta$-glucose by inversion of the anomeric configuration (26). In addition, they also hydrolyze, but at a lower rate, $\alpha-1,6$ glycosidic linkages of $\operatorname{starch}(20)$.

The conversion of starch into sugar, syrups and dextrins by action of amylases represents the larger part of the starch processing industry (27). The hydrolytes are used as carbon source in fermentation, as well as sources of sweetness in a range of manufactured food products and beverages. Amylases are used in the liquefaction of insoluble starch, manufacture of oligosaccharides mixtures (substitutes sucrose preventing crystallization in foods and keeping a certain level of hardness of the texture during storage), maltotetraose syrup (to control the freezing points of frozen foods) and of high molecular weight branched dextrins (used as extender and glozing agent for production of powdery foods and rice cakes). Manufacturing starch to maltose is important since that this disaccharide is widely used as sweeter and also as intravenous sugar supplement. In food industries is used due of low tendency to be crystallized and relative nonhygroscopic. To manufacture of high fructose containing syrups, the starch is first converted to glucose by enzymes liquefaction and saccharification.

Several fungal species produce glucoamylases, for instance, Aspergillus awamori, A. terreus and Rhizopus oryzae (21).

*Corresponding Author. Mailing address: Avenida Bandeirantes, 3900, bloco 10, Departamento de Biologia, FFCLRP-USP 14040-901 Ribeirão Preto, São Paulo, Brazil. Phone/Fax: + 5516 3602-4680/ + 5516 3602-4886. E-mail: polizeli@fffclrp.usp.br 
Glucoamylases produced by fungi, generally, occur in multiple forms. They have two domains, a catalytic domain and a starch binding domain. These domains are connected by an $O$ glycosylated polypeptide linker located at the $\mathrm{N}$-terminus (20). Total or partial proteolytic excision of the starch binding domains leads to the formation of glucoamylase capable of hydrolyzing only soluble starch (8).

The fungus Scytalidium thermophilum belongs to the thermophilic Torula-Humicola complex which has more than thirty isolates with species very variable in macroscopical and microscopical features (24). In our laboratory we previously studied Scytalidium thermophilum 15.1 and 15.8, which were excellent producers of trehalase (14) and of conidial and mycelial alkaline phosphatases (13). Regarding amylase activity, substantial differences were detected between S. thermophilum 15.1 and 15.8 isolates. The aim of the present study was to compare some biochemical properties of the glucoamylase produced by the mycelial extracts of fungi $S$. thermophilum 15.1 and 15.8 . The high amylolytic activity produced by the two strains suggested potential for applications in the saccharification starch process.

\section{MATERIALS AND METHODS}

\section{Microorganism and culture}

The S. thermophilum isolates 15.1 (= CBS 619.91) and $15.8(=$ CBS 671.88 = ATCC 669.38) were maintained on slants of solid $4 \%$ oatmeal baby food (Quaker) medium, at $45^{\circ} \mathrm{C}$. Liquid cultures were prepared in $50 \mathrm{ml}$ of M-5 liquid medium (22), inoculated with of $2.0 \mathrm{ml}$ of a spore suspension $\left(10^{5}\right.$ spores $\left./ \mathrm{ml}\right)$, in $250 \mathrm{ml}$ Erlenmeyer flasks. The culture conditions were standardized according to the exigency of each fungus for maximal enzymatic production, i.g., incubated at $45^{\circ} \mathrm{C}$, without agitation, and for 5 or 7 days, respectively, for 15.1 and 15.8 isolates.

\section{Preparation of crude mycelial extract}

The cultures were harvested by vacuum filtration on Whatman \#1 and the mycelial pads were ground in a porcelain mortar with twice their weight of acid- washed sea sand, at $4^{\circ} \mathrm{C}$, extracted in distillated water and centrifuged at $23,700 \mathrm{xg}$ for 15 min. The supernatant was the source of crude mycelial extract.

\section{Determination of glucoamylase activity and protein}

The glucoamylase activity was determined using $1 \%$ starch as substrate in $0.1 \mathrm{M}$ sodium acetate buffer, $\mathrm{pH} 5.5$. The reducing sugars formed were quantified according to Miller (18) using dinitrosalicylic acid (DNS). The glucoamylase activity was also determined on maltose, starch, amylopectin and glycogen, as substrates by glucose oxidase method according to Bergmeyer \& Bernt (3). One unit of glucoamylase activity was defined as the amount of enzyme that releases one mmol of glucose per minute. The protein was quantified according to Lowry (16) using bovine serum albumin as standard. Specific activity corresponds to $\mu \mathrm{mol} / \mathrm{min} / \mathrm{mg}$ prot.

\section{Purification and biochemical characterization}

Mycelial glucoamylase of $S$. thermophilum 15.1 was purified using a DEAE-Celullose column (21 x $60 \mathrm{~mm})$ equilibrated in $0.01 \mathrm{M}$ sodium acetate buffer, $\mathrm{pH} 5.5$ and two forms (I e II) were separated. The form I did not interact with the resin, and the fractions with amylolytic activity were pooled and applied to a CM-Celullose chromatographic column $(21 \times 60 \mathrm{~mm})$ equilibrated in the same buffer. The enzyme was eluted as single form, using a linear gradient of $\mathrm{NaCl}(0-0.5 \mathrm{M})$, in the same buffer. The fractions with amylase activity were pooled, dialyzed overnight at $4^{\circ} \mathrm{C}$, and used for biochemical characterization. The form II was eluted using a linear gradient of $\mathrm{NaCl}(0-1.0 \mathrm{M})$ in the same buffer but it has not representative amylolytic levels.

Glucoamylase of S. thermophilum 15.8 was purified also by two chromatographic steps. The crude extract was applied to a CM-Celullose column $(21 \times 60 \mathrm{~mm})$ and eluted as a single form under the same condition mentioned above. The fractions with amylase activity were pooled, dialyzed overnight at $4^{\circ} \mathrm{C}$ and applied to a Concanavalin A-Sepharose column $(10 \times 50 \mathrm{~mm})$, equilibrated with $0.020 \mathrm{M}$ Tris-HCl buffer, $\mathrm{pH} 7.5$ added of $0.5 \mathrm{M}$ $\mathrm{NaCl}, 0.5 \mathrm{mM} \mathrm{Mn}^{++}$and $\mathrm{Ca}^{++}$. The enzyme was eluted as a single form using a linear gradient of methyl $\alpha$-D-mannopyranoside ( 0 $0.5 \mathrm{M}$ ), pooled, dialyzed overnight at $4^{\circ} \mathrm{C}$, and used for biochemical characterization.

\section{Electrophoresis}

The samples of purified enzymes were run under nondenaturing electrophoresis in polyacrylamide $7 \%$ gels PAGE, Davis (9) and stained for protein with $\mathrm{AgNO}_{3}$ according to Blum (4).

\section{Molecular mass and carbohydrate content determination}

The molecular mass of glucoamylase produced by $S$. thermophilum was estimated by gel filtration in a Sephadex G100 column $(20 \times 860 \mathrm{~mm})$, equilibrated in $0.05 \mathrm{M}$ Tris- $\mathrm{HCl}$ buffer, $\mathrm{pH} 7.5$ added of $0.1 \mathrm{M} \mathrm{KCl}$, using as molecular mass markers alcohol dehydrogenase $(150 \mathrm{kDa}), \mathrm{BSA}(66 \mathrm{kDa})$, carbonic anhydrase $(29 \mathrm{kDa})$ and cytochrome-c $(14 \mathrm{kDa})$. The protein carbohydrate content was determined according to Dubois (10).

\section{Kinetic parameters}

The kinetic parameters (Km and Vmax) were determined using starch, maltose, amylopectin and glycogen as substrate by the Lineweaver-Burk graphic representation (15).

\section{Thin layer chromatography}

Chromatographic analysis of the reaction end products of glucoamylase activity produced by $S$. thermophilum 15.1 e 15.8 
was carried out using TLC. The reaction mixture was concentrated and applied $(10 \mu \mathrm{l})$ on silica gel, and two ascendent chromatographic steps were applied, using butanol/ethanol/ water $(5: 3: 2)$ as solvent system. Spots were developed by spraying the air-dried plate with $\mathrm{H}_{2} \mathrm{SO}_{4}$ and methanol (1:9) containing $0.2 \%$ orcinol and heating at $100^{\circ} \mathrm{C}(12)$.

\section{RESULTS AND DISCUSSION}

\section{Enzyme purification}

Crude mycelial extract of $S$. thermophilum 15.1 was submitted to chromatography in DEAE-Cellulose (Fig. 1A). Two isoforms (I and II) with amylolytic activities were separated. The form I contained approximately $86 \%$ of total amylolytic activity and it did not interact with the resin. Form II, with $14 \%$ of total amylolytic activity was eluted as single form with 0.58 $\mathrm{M} \mathrm{NaCl}$, using a linear gradient $(0-1.0 \mathrm{M})$. The fractions of form I were pooled, dialyzed against buffer and applied to a CMCellulose chromatographic column (Figure 1B). The amylolytic activity eluted as single form with $0.16-0.28 \mathrm{M} \mathrm{NaCl}$, with a linear gradient $(0-0.5 \mathrm{M})$.

S. thermophilum 15.8 crude mycelial extract was applied to a CM-Cellulose chromatographic column (Fig. 1C), and eluted with a linear $\mathrm{NaCl}$ gradient $(0-0.5 \mathrm{M})$. The fractions with glucoamylase activity eluted as a single form with $0.18 \mathrm{M} \mathrm{NaCl}$. The activity fraction were pooled, dialyzed, applied to a Concanavalin A-Sepharose column (Fig. 1D) and eluted as single form with $0.05-0.1 \mathrm{M}$ methyl $\alpha$-D-mannopyranoside using a linear gradient $(0-0.5 \mathrm{M})$.

The enzymes of the strains 15.1 and 15.8 were purified 141 fold and 71.23 -fold, with recovery of $5.45 \%$ and $7.38 \%$, respectively (Table 1). Only a single band on 7\% PAGE was observed for the intracellular glucoamylase of strain 15.1, stained for protein by silver and stained for glucoamylase activity (Fig. 2).

\section{Molecular mass determination}

Molecular masses of intracellular glucoamylases of $S$. thermophilum 15.1 and 15.8 determined by Sephadex G-100 gel filtration were, respectively, $54 \mathrm{kDa}$ and $98.7 \mathrm{kDa}$. These values are in agreement with the literature that reports that the molecular masses of fungal glucoamylases are in the range 48$90 \mathrm{kDa}$ (20), as those of T. lanuginosus (26), Chaetomium thermophilum (7) and Sclerotinia sclerotiorum (17). However, a higher value of $125 \mathrm{kDa}$ was reported for Aspergillus niger glucoamylase (25).

Usually, the carbohydrate content of fungal glucoamylase is in the range of $10-20 \%$, as observed for Rhizopus niveus (29). But, lower values were observed such as that of the glucoamylase of Neurospora crassa (5.1\%) (23). Intracellular glucoamylases of S. thermophilum 15.1 and 15.8 had carbohydrate contents of $20 \%$ and $51 \%$, respectively.

\section{Temperature and pH optima and thermal stability}

The values of temperature optima for glucoamylases of the strains 15.1 and 15.8 were compatible with the literature, which reports values among $50^{\circ} \mathrm{C}$ to $70^{\circ} \mathrm{C}(20)$. Intracellular glucoamylase of $S$. thermophilum 15.1 exhibited optimum temperature of $50^{\circ} \mathrm{C}$ and $55^{\circ} \mathrm{C}$, with maltose and starch as substrates (Fig. $3 \mathrm{~A}$ ), and $60^{\circ} \mathrm{C}$ with either substrates for the intracellular glucoamylase of S. thermophilum 15.8 (Fig. 3B). A temperature optimum of $50^{\circ} \mathrm{C}$ is reported for S. sclerotiorum glucoamylase (17). Higher activity temperatures were verified also for glucoamylase of Thermomyces lanuginosus (26), Chaetomium thermophilum (7) and Trichoderma reesei (11). Mycelial enzymes of S. thermophilum have $t_{50}$ of $11 \mathrm{~min}$ and 15 min (strain 15.1) (Fig. 3C), and more than $60 \mathrm{~min}$ for strain 15.8 (Fig. 3D), at $60^{\circ} \mathrm{C}$, when starch and maltose, respectively, were used as substrates. Glucoamylase of Chaetomium thermophilum retained $50 \%$ active after $60 \mathrm{~min}$, at $65^{\circ} \mathrm{C}(7)$. The high percentage of carbohydrate content of the glucoamylase of $S$. thermophilum 15.8 , could be responsible by the higher thermal stability compared to $S$. thermophilum 15.1 glucoamylase.

Intracellular glucoamylase of $S$. thermophilum 15.1 had a $\mathrm{pH}$ optimum of 5.0 when starch or maltose used as substrates (Fig. 4A), and the mycelial glucoamylase of S. thermophilum 15.8 has $\mathrm{pH}$ optimum in the range of 5.5-6.0, either with starch or maltose (Fig. 4B). Similar results were obtained for extracellular

Table 1. Purification of glucoamylases produced by S. thermophilum 15.1 and 15.8.

S. thermophilum 15.1 S. thermophilum 15.8

\begin{tabular}{lccccccccccc}
\hline \multirow{1}{*}{ Step } & $\begin{array}{c}\text { Activity } \\
\text { (Total U) }\end{array}$ & $\begin{array}{c}\text { Protein } \\
\text { (Total mg) }\end{array}$ & $\begin{array}{c}\text { Specific } \\
\text { Activity } \\
\text { (U/mg prot) }\end{array}$ & $\begin{array}{c}\text { Yield Purification } \\
(\%)\end{array}$ & $\begin{array}{c}\text { Activity } \\
\text { fold }(\mathrm{X})\end{array}$ & $\begin{array}{c}\text { Protein } \\
\text { (Total U) }\end{array}$ & $\begin{array}{c}\text { Specific } \\
\text { (Total mg) }\end{array}$ & $\begin{array}{c}\text { Yield Purification } \\
\text { Activity } \\
(\%)\end{array}$ & $\begin{array}{c}\text { Pold }(\mathrm{X}) \\
\text { (U/mg prot) }\end{array}$ \\
\hline Crude extract & 72.27 & 235.06 & 0.31 & 100 & 1 & 40.92 & 305.80 & 0.13 & 100 & 1 \\
DEAE-Celullose & 7.39 & 1.98 & 3.73 & 10.22 & 12.03 & - & - & - & - & - \\
CM-Celullose & 3.94 & 0.09 & 43.77 & 5.45 & 141.2 & 4.37 & 1.32 & 3.31 & 10.68 & 25.46 \\
Con A- Sepharose & - & - & - & - & - & 3.02 & 0.32 & 9.44 & 7.38 & 71.23 \\
\hline
\end{tabular}




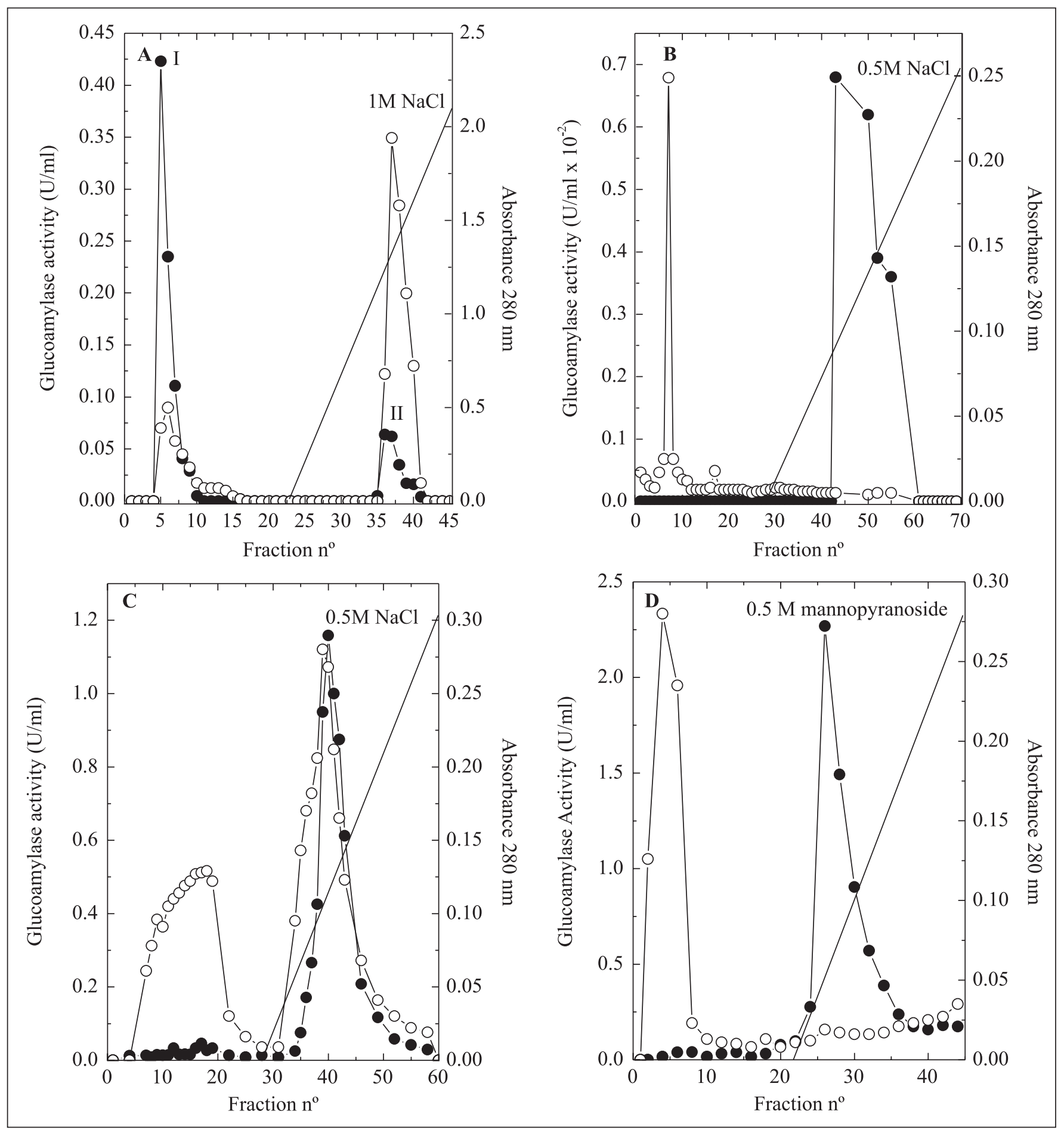

Figure 1. Chromatographic profiles of the glucoamylases produced by fungi S. thermophilum 15.1 (A and B) and $15.8(\mathrm{C}$ and D), on DEAE-Cellulose (A), CM-Cellulose (B and C) and Concanavalin A-Sepharose (D). Symbols: (O) glucoamylase activity; (O) absorbance $280 \mathrm{~nm}$. 

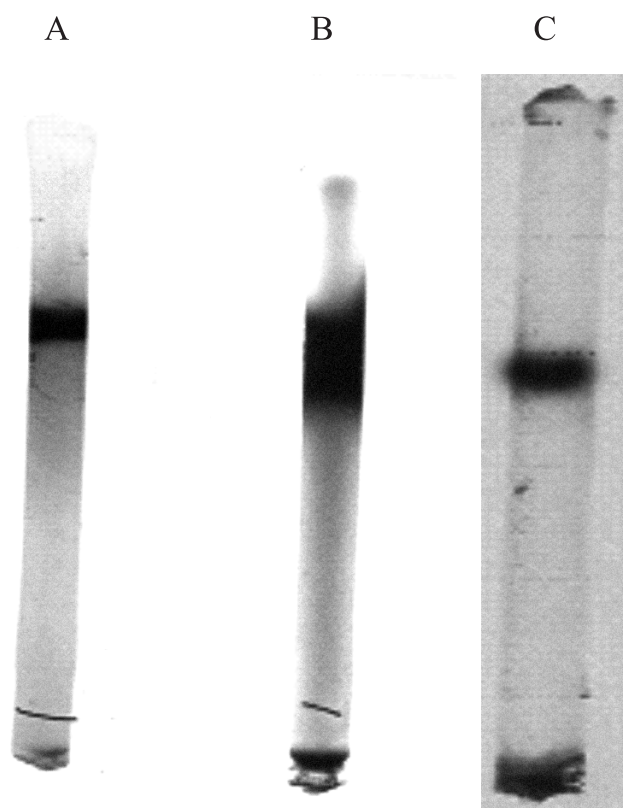

Figure 2. 7\% PAGE stained for glucoamylase activity using starch (A) and maltose (B), and stained for protein by silver (C).

glucoamylase of $S$. thermophilum 15.1 (5), Thermomyces lanuginosus (26), Arthrobotrys amerospora (20) and Neurospora crassa (23). The values obtained were higher than those reported for S. sclerotiorum (3.5-4.0) (17). Generally, glucoamylases obtained from fungi are active at acidic $\mathrm{pH}$ values. However, several forms have variable values of $\mathrm{pH}$ optimum.

\section{Influence of ions on the glucoamylase activity}

The influence of different ionic compounds on the glucoamylase activities is shown in Table 2. The intracellular glucoamylase activity of $S$. thermophilum 15.1 was enhanced $23-36 \%$ by addition of $\mathrm{Mn}^{2+}$, but strongly inhibited by $\mathrm{Cu}^{2+}$, $\mathrm{Hg}^{2+}$ and $\beta$-mercaptoethanol. These last two metallic ions drastically reduced the 15.8 glucoamylase activity, but in contrast, $\mathrm{Cu}^{2+}$ enhanced 23 or $74 \%$ the glucoamylase activity, depending on the substrate, starch or maltose, respectively.

The inhibition promoted by $\beta$-mercaptoethanol indicates the existence of disulfide bonds in the enzyme molecule. $S$. thermophilum 15.8 glucoamylase was also enhanced by $5 \mathrm{mM}$ $\mathrm{Ba}^{2+}, \mathrm{Mg}^{2+}, \mathrm{Na}^{+}, \mathrm{NH}_{4}^{+}$, and $\mathrm{Ca}^{2+}$. For both species of $S$. thermophilum were verified considerable differences on glucoamylase activity determined with the substrates starch or maltose in the presence of $\mathrm{Mn}^{2+}$ and $\mathrm{Zn}^{2+}$. Glucoamylase of $C$. thermophilum was more active in the presence of $\mathrm{Ca}^{2+}, \mathrm{Mg}^{2+}$, $\mathrm{Na}^{+}$and $\mathrm{K}^{+}$, and inhibited by $\mathrm{Fe}^{2+}, \mathrm{Ag}^{+}$and $\mathrm{Hg}^{2+}(7) . \mathrm{Mn}^{2+}$ and $\mathrm{Zn}^{2+}$ enhanced glucoamylase activity from Humicola grisea var. thermoidea (28) and lower concentrations of $\mathrm{Mn}^{2+}$ and $\mathrm{Ca}^{2+}$ enhanced the activity of glucoamylase of S. sclerotiorum (17).
Table 2. Effect of ions and other compounds on the glucoamylases produced by $S$. thermophilum 15.1 and 15.8 .

\begin{tabular}{lcccc}
\hline \multirow{2}{*}{$\begin{array}{c}\text { Ions/ } \\
\text { Compounds }\end{array}$} & \multicolumn{3}{c}{$\begin{array}{c}\text { S. thermophilum } \\
\text { 15.1 }\end{array}$} & $\begin{array}{c}\text { S. thermophilum } \\
15.8\end{array}$ \\
\cline { 2 - 5 } & \multicolumn{5}{c}{ Starch } & Maltose & Starch & Maltose \\
\cline { 2 - 5 } & 100 & 100 & 100 & 100 \\
\hline None & 40 & 24 & 0 & 0 \\
$\beta-m e r c a p t o e t h a n o l$ & 70 & 67 & 121 & 98 \\
$\mathrm{BaCl}_{2}$ & 78 & 65 & 109 & 139 \\
$\mathrm{CaCl}_{2}$ & 48 & 38 & 123 & 174 \\
$\mathrm{CuCl}_{2}$ & 7 & 26 & 0 & 0 \\
$\mathrm{HgCl}_{2}$ & 101 & 80 & 140 & 108 \\
$\mathrm{MgCl}_{2}$ & 94 & 86 & 134 & 86 \\
$\mathrm{MgSO}_{4}$ & 123 & 136 & 59 & 203 \\
$\mathrm{MnCl}_{2}$ & 95 & 73 & 116 & 76 \\
$\mathrm{NaCl}$ & 104 & 76 & 131 & 88 \\
$\mathrm{NH}_{4} \mathrm{Cl}$ & 93 & 12 & 83 & 61 \\
$\mathrm{ZnCl}_{2}$ & &
\end{tabular}

\section{Kinetic properties}

The kinetic parameters obtained for the glucoamylase of $S$. thermophilum 15.1 are shown in Table 3. The enzyme possesses greater affinity to maltose $(\mathrm{Km} 0.029 \mathrm{mg} / \mathrm{ml})$ than for starch $(\mathrm{Km}$ $0.094 \mathrm{mg} / \mathrm{ml}$ ), which was confirmed by the values of catalytic efficiency. But, probably, the hydrolysis of starch and maltose occurred at the same catalytic site, considering that the rate of hydrolysis of a mixture of starch and maltose $(35 \mathrm{U} / \mathrm{ml})$ was intermediary when compared with that of the individual substrates ( $42 \mathrm{U} / \mathrm{ml}$ for starch and $12.5 \mathrm{U} / \mathrm{ml}$ for maltose), and lower than the addition of both ( $54.5 \mathrm{U} / \mathrm{ml}$ approximately). The enzyme showed reduced affinity by glycogen.

Both enzymes, GAs 15.1 and 15.8, hydrolyzed starch and maltose as substrate, and glucose was always the main hydrolysis product (Fig. 5), but S. thermophilum 15.8 formed maltotriose when maltose was the substrate, in contrast with $S$. thermophilum 15.1. In according to Thorsen (26), di-, tri- and tetrasacharide can be formed reversibly from high glucose concentrations.

We previously reported the purification of the extracellular amylases produced by S. thermophilum 15.1 and 15.8 and significant differences were detected between the enzymes of the two isolates. The first one (15.1) produced an extracellular glucoamylase (1) and an $\alpha$-amylase (2), which were isolated and purified by chromatographic methods. But, in contrast, under the same conditions, it was no detected $\alpha$-amylase activity in $S$. thermophilum 15.8 , but two isoforms of glucoamylase were separated and characterized $(5 ; 6)$. Here, 


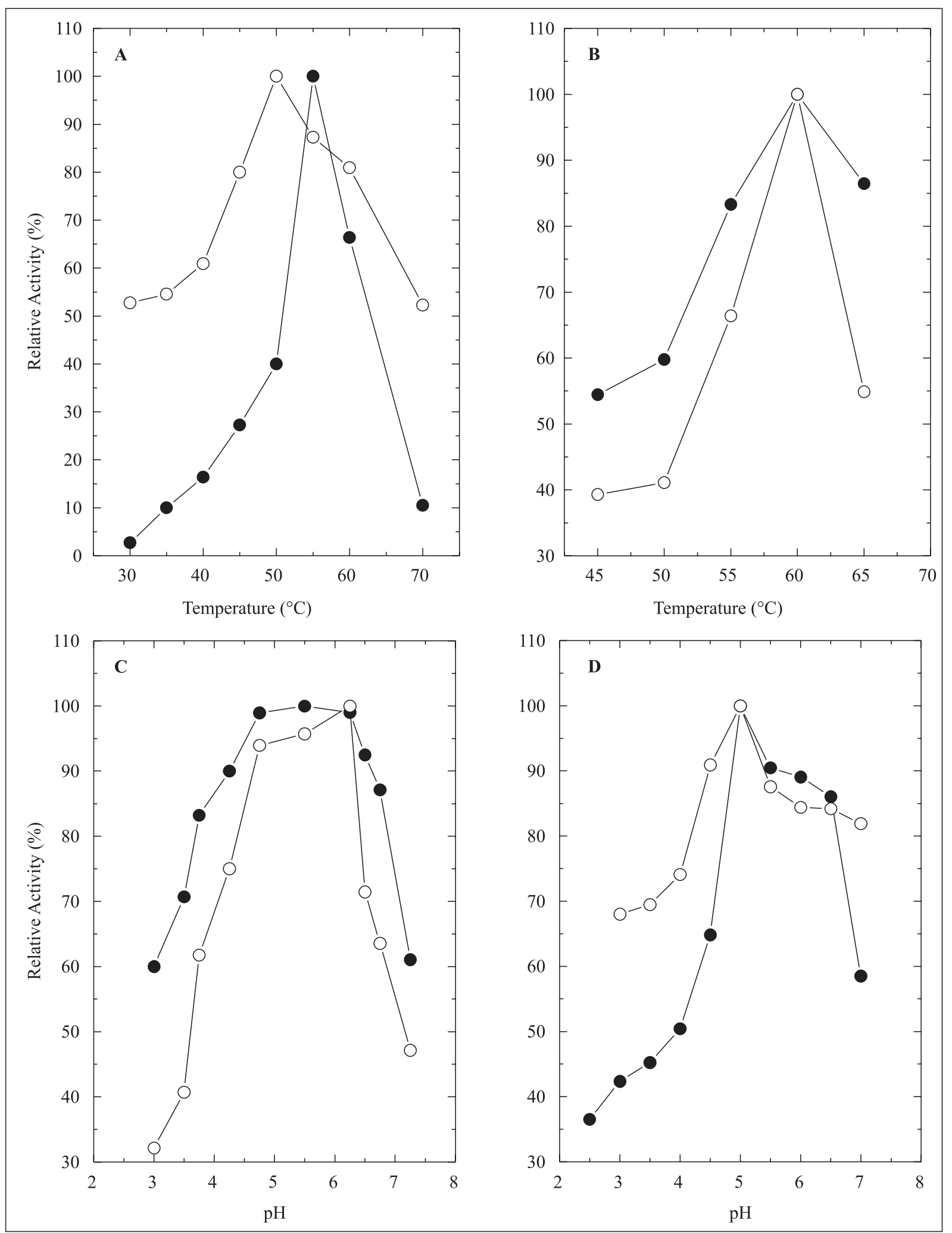

Figure 3. Optima temperature (A and B) and thermal stability on $60^{\circ} \mathrm{C}(\mathrm{C}$ and $\mathrm{D})$ of the glucoamylases produced by $S$. thermophilum $15.1(\mathrm{~A}$ and $\mathrm{C})$ and $15.8(\mathrm{~B}$ and $\mathrm{D})$, using starch $(\mathbf{O})$ and maltose $(\mathrm{O})$ as substrate. 


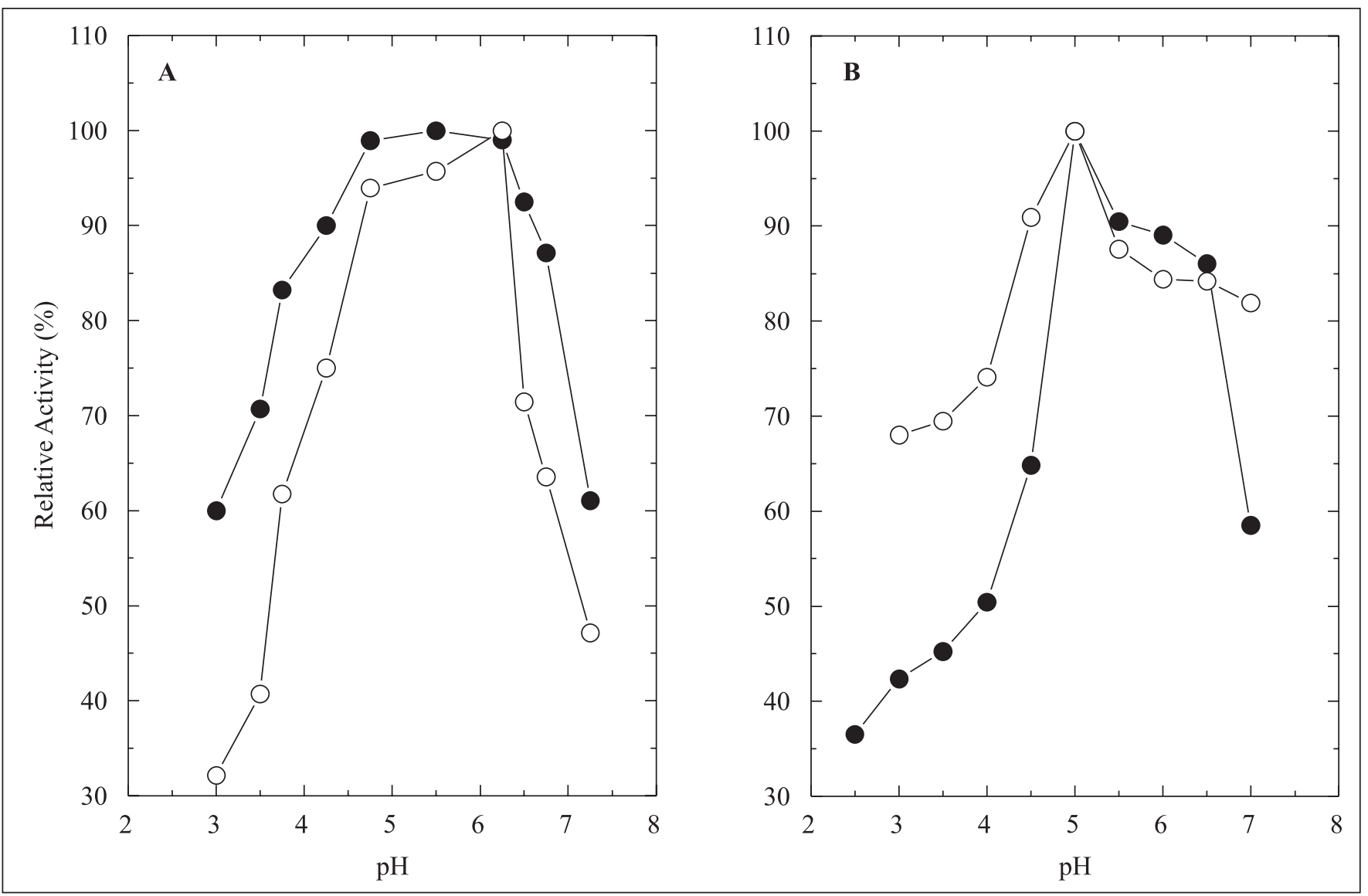

Figure 4. Optimum $\mathrm{pH}$ of activity for the glucoamylases produced by $S$. thermophilum 15.1 (A) and 15.8 (B), using starch (O) and maltose $(O)$ as substrate.

Table 3. Determination of kinetic parameters of the purified glucoamylase produced by $S$. thermophilum 15.1 .

\begin{tabular}{lccc}
\hline Substrate & $\begin{array}{c}\mathrm{Km} \\
(\mathrm{mg} / \mathrm{ml})\end{array}$ & $\begin{array}{c}\text { Vmax } \\
(\mu \mathrm{mol} / \mathrm{min} / \mathrm{mg} \text { prot })\end{array}$ & $\begin{array}{c}\text { Vmax } / \\
\mathrm{Km}\end{array}$ \\
\hline Starch & 0.094 & 0.202 & 2.15 \\
Maltose & 0.029 & 0.109 & 3.76 \\
Starch + Maltose & 0.003 & 0.070 & 2.33 \\
Glycogen & 0.158 & 0.185 & 1.17 \\
Amylopectin & 0.045 & 0.016 & 0.35 \\
\hline
\end{tabular}

mycelial extracts from two species were purified by two different sequential chromatographic steps. Optimal temperature and $\mathrm{pH}$, for starch and maltose as substrates, were close between the two species $\left(50-60^{\circ} \mathrm{C}\right.$ and $\left.\mathrm{pH} 5.0-6.0\right)$ but differences were observed as for effect of metallic ions, thermostability, kinetic constants, molecular masses 15.1 and 15.8 and products of hydrolysis. In relation at molecular mass, for example, for $S$. thermophilum 15.1, extra (1) and intracellular glucoamylase had close values (60 $\mathrm{kDa}$ and $54 \mathrm{kDa}$, respectively), but in contrast, differences were observed to extracellular GAI (68.5 $\mathrm{kDa})(6)$, GAII ( $83 \mathrm{kDa})(5)$ and to the intracellular form (98.7 $\mathrm{kDa}$ ) from $S$. thermophilum 15.8. These results reflect differences structural or in the carbohydrate content since that extracellular glucoamylases of S. thermophilum 15.1 and 15.8 had carbohydrate contents of $9.8 \%$ and $10-25 \%(1,5,6)$, but intracellular glucoamylases of S. thermophilum 15.1 and 15.8 had carbohydrate contents of $20 \%$ and $51 \%$, respectively. Then, S. thermophilum is a potential thermophilic fungus with highest amylolytic levels either extra or intracellular with great possibility industrial application.

\section{ACKNOWLEDGEMENTS}

This work was supported by grants from Conselho de Desenvolvimento Científico e Tecnológico (CNPq) and Fundação de Amparo a Pesquisa do Estado de São Paulo (FAPESP). H.F.T, J.A.J and M.L.T.M.P. are Research Fellows of CNPq. We thank Amauri Pinhal e Maurício de Oliveira for technical assistance. 

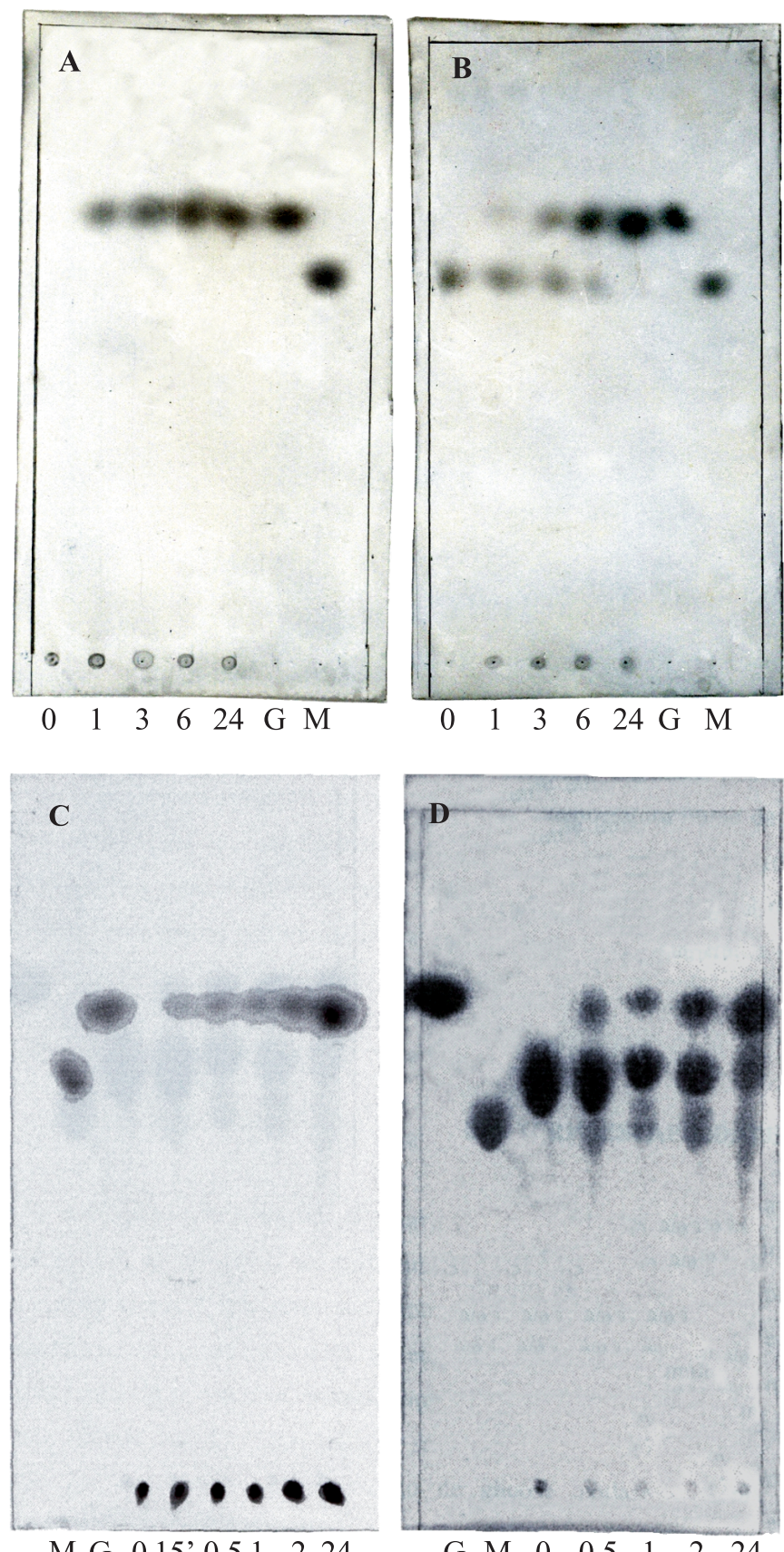

M G $015^{\prime} \quad 0,51224$

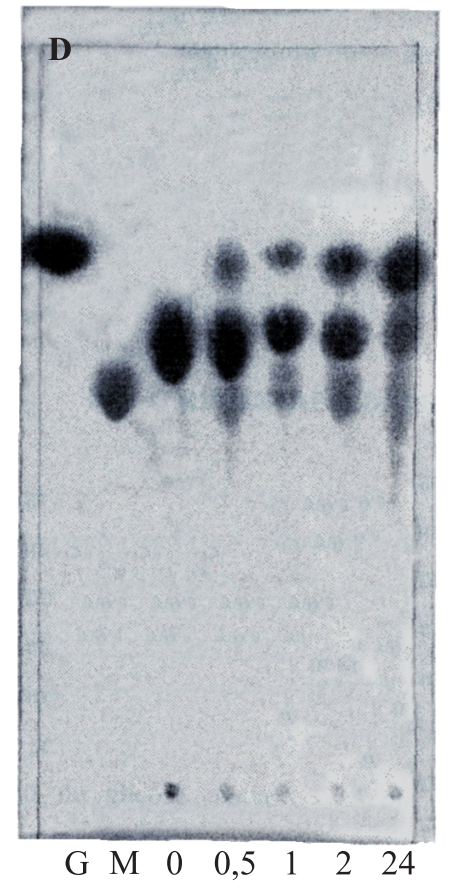

Time

Figure 5. Thin layer chromatography of the hydrolysis products of the glucoamylases of Scytalidium thermophilum 15.1 (A,B) and Scytalidium thermophilum 15.8 (C,D) using starch (A,C) and maltose $(B, D)$ as substrates. $G=$ glucose; $m=$ maltose. Time is represented in hours, except 15 (minutes).

\section{RESUMO}

\section{Glucoamilases miceliais produzidas pelas linhagens 15.1 e 15.8 do fungo termofílico Scytalidium thermophilum: Purificação e Caracterização Bioquímica.}

Duas linhagens (15.1 e 15.8) do fungo termofílico Scytalidium thermophilum se mostraram produtoras de grandes quantidades de glucoamilases, com potencial aplicação industrial. A isoforma I de glucoamilase produzida pela linhagem 15.1 foi submetida seqüencialmente a cromatografia em colunas de DEAE-celulose e CM-celulose, sendo purificada 141 vezes com porcentagem de recuperação de 5,45\%. A glucoamilase da linhagem 15.8 foi purificada 71 vezes através do uso de colunas de cromatografia de CM-celulose e Concanavalina ASepharose com porcentagem de recuperação de $7,38 \%$. Temperatura e $\mathrm{pH}$ ótimo foram de $50-60^{\circ} \mathrm{C}$ e $5,0-6,0$ respectivamente, utilizando-se amido e maltose como substratos. A glucoamilase de $S$. thermophilum 15.8 se mostrou mais estável $\left(\mathrm{t}_{50}>60 \mathrm{~min}\right)$ que a de $S$. thermophilum $15.1\left(\mathrm{t}_{50}\right.$ $=11-15 \mathrm{~min}) \mathrm{a} 60^{\circ} \mathrm{C}$. As glucoamilases tiveram suas atividades enzimáticas aumentadas na presença de vários íons (ex: $\mathrm{Mn}^{2+}$, e $\mathrm{Ca}^{2+}$ ) e inibidas por $\beta$-mercaptoetanol. A glucoamilase da linhagem 15.1 apresentou um Km de 0,094 mg/ml e 0,029 mg/ml and Vmax de 202U/mg prot e 109U/mg prot, para amido e maltose respectivamente. A análise do produto da hidrólise de amido e maltose por TLC, demonstrou que o produto final era glucose, confirmando as características da enzima como glucoamilase. Diferenças entre as duas linhagens foram observadas com relação aos produtos formados tendo maltose como susbstrato, a linhagem $15.8 \mathrm{de}$ S. thermophilum produziu maltotriose como produto final em contrate com a linhagem 15.1.

Palavras-chave: glucoamilase, amilase, Scytalidium thermophilum, enzima termoestável, hidrólise de amido

\section{REFERENCES}

1. Aquino, A.C.; Jorge, J.A.; Terenzi, H.F.; Polizeli, M.L.T.M. (2001). Termostable glucose-tolerant glucoamylase produced by the thermophilic fungus Scytalidium thermophilum. Folia Microbiol., 46 (1), 11-16.

2. Aquino, A.C.M.M.; Jorge, J.A.; Terenzi, H.F.; Polizeli, M.L.T.M. (2003). Studies on a termostable $\alpha$-amylase from the thermophilic fungus Scytalidium thermophilum. Appl. Microbiol. Biotechnol., 61, 323-328.

3. Bergmeyer, H.U.; Bernt, E. (1974). Methods of enzymatic analysis. H.U. Bergmeyer, Verlag-Chimie Academic Press, New York, 1205 $1215 \mathrm{p}$.

4. Blum, H.; Beier, H.; Gross, H.J. (1987). Improved silver staining of plant protein, RNA and DNA in polyacrylamide gels. Electrophoresis, 81, 93-99.

5. Cereia, M.; Guimarães, L.H.S.; Peixoto-Nogueira, S.C.; Jorge, J.A.; Terenzi, H.F.; Greene, J.L.; Polizeli, M.L.T.M. (2006). Glucoamylase isoform (GAII) purified from a thermophilic fungus Scytalidium 
thermophilum 15.8 with biotechnological potential. Afr. J. Biotechnol., 5 (12), 1239-1245.

6. Cereia, M.; Terenzi, H.F.; Jorge, J.A.; Greene, L.J.; Rosa, J.C.; Polizeli, M.L.T.M. (2000). Glucoamylase activity from the thermoplilic fungus Scytalidium thermophilum. Biochemical and regulatory properties. J. Basic Microbiol., 2, 83-92.

7. Chen, J.; Li, D.; Zhang, Y.; Zhou, Q. (2005). Purification and characterization of a termostable glucoamylase from Chaetomium thermophilum. J. Gen. Appl. Microbiol., 55, 175-181.

8. Coutinho, P.M.; Reilly, P.J. (1997). Glucoamylase, structural, functional and evolutionary relationships. Proteins, 29, 334-347.

9. Davis, B.J. (1964). Disc electrophoresis II. Method and application to human serum proteins. Ann. NY Acad. Sci., 121, 407-427.

10. Dubois, M.; Gilles, K.; Hamilton, J.; Rebers, P.; Smith, F. (1956). Colorimetric methods for determination of sugar and related substances. Anal. Chem., 28, 350-356.

11. Fagerstrom, R.; Kalkkinen, N. (1995). Characterization, subsite mapping and partial amino acid sequence of glucoamylase from the filamentous fungus Trichoderma reesei. Biotechnol. Appl. Biochem., 21, 223-231.

12. Fontana, J.D.; Gebara, M.; Blumel, M.; Schneider, H.; Mackenzie, C.R.; Johnson, K.G. (1988). $\alpha$-4-O-methyl-D-glucuronidase component of xylanolytic complexes. Methods Enzymol., 160, 560-571.

13. Guimarães, L.H.S.; Terenzi, H.F.; Jorge, J.A.; Polizeli, M.L.T.M. (2001). Termostable conidial and mycelial alkaline phosphatases from the thermophilic fungus Scytalidium thermophilum. J. Ind. Microbiol. Biotechnol., 27, 265-270.

14. Kadowaki, M.K.; Polizeli, M.L.T.M.; Terenzi, H.F.; Jorge, J.A. (1996). Characterization of trehalase activities from the thermophilic fungus Scytalidium thermophilum. Biochim. Biophys. Acta, 1291, 199205.

15. Lineweaver, H.; Burk, D. (1934). The determination of the enzyme dissociation. J. Am. Chem. Soc., 56, 658-666.

16. Lowry, O.H.; Rosebrough, N.J.; Farr, A.L.; Randall, R.J. (1951). Protein measurement with the folin phenol reagent. J. Biol. Chem., 193, 265-275.

17. Martel, M.B.; Penhoat, C.H.; Létoublon, R.; Fèvre, M. (2002). Purification and characterization of a glucoamylase secreted by plant pathogen Sclerotinia sclerotiorum. Can. J. Microbiol., 48, 212-218.
18. Miller, G.H. (1959). Use of dinitrosalicylic acid reagent for determination of reducing sugar. Anal. Chem., 31, 426-429.

19. Norouzian, D.; Akbarzadeh, A.; Scharer, J.M.; Young, M.M. (2006). Fungal glucoamylases. Biotechnol. Adv., 24, 80-85.

20. Norouzian, D.; Rostami, K.; Nouri, I.D.; Saleh, M. (2000). Subsite mapping of purified glucoamylases I, II, III produced by Arthrobotrys amerospora ATCC 34468. World J. Microbiol. Biotechnol., 16, 155161.

21. Pandy, A.; Nigam, P.; Soccol, C.R.; Soccol, V.T.; Singh, D.; Mohan, R. (2000). Advances in microbial amylases. Biotechnol. Appl. Biochem., 31, 135-152.

22. Peralta, R.M.; Terenzi, H.F.; Jorge, J.A. (1990). $\beta$-D glycosidase activities of Humicola grisea: biochemical and kinetic characterization of a multifuntional enzyme. Biochim. Biophys. Acta, 1033, 243-249.

23. Spinelli, B.B.L.; Polizeli, M.L.T.M.; Terenzi, H.F.; Jorge, J.A. (1996). Biochemical characterization of glucoamylase from hyper producer exo-1 mutant strain of Neurospora crassa. FEMS Microbiol. Lett., 138, 173-177.

24. Straatsma, G.; Samson, R.A. (1993). Taxonomy of Scytalidium thermophilum, an important fungus in mushroom compost. Mycol. Res., 97 (3), 321-328.

25. Suresh, C.; Dubey, A.K.; Srikanta S.; Kumar, U.S. (1999). Characterization of starch hydrolyzing enzyme of Aspergillus niger. Appl. Microbiol. Biotechnol., 51, 673-675.

26. Thorsen, T.S.; Johnsen, A.H.; Josefsen, K.; Bensen, B. (2006). Identification and characterization of glucoamylase from the fungus Thermomyces lanuginosus. Biochem. Biophys. Acta, 1764, 671676.

27. Torres, R.; Pessela, B.C.; Mateo, C.; Ortiz, C.; Fuentes, M.; Guisan, J.M. (2004). Reversible immobilization of glucoamylase by ionic adsorption on SEPA beads coated with polyethyleneimine. Biotechnol. Prog., 20 (4), 1297-1300.

28. Tosi, L.R.O.; Terenzi, H.F.; Jorge, J.A. (1993). Purification and characterization of an extracellular glucoamylase from the thermophilic Humicola grisea var. thermoidea. Can. J. Microbiol., $39,846-852$.

29. Ueda, S. (1981). Fungal glucoamylase and raw starch digestion. TIBS 6, 89-90. 